\title{
Eliglustat tartrate for the treatment of adults with type I Gaucher disease [Corrigendum]
}

Bennett LL, Turcotte K. Drug Des Devel Ther. 2015;9:

4639-4647.

On page 4642, left column, 2nd word, the drug name Cardelga $^{\circledR}$ should have been Cerdelga ${ }^{\circledR}$.

On page 4643, Table 2, the drug name Cardelga ${ }^{\circledR}$ should have been Cerdelga ${ }^{\circledR}$.

\section{Publish your work in this journal}

Drug Design, Development and Therapy is an international, peerreviewed open-access journal that spans the spectrum of drug design and development through to clinical applications. Clinical outcomes, patient safety, and programs for the development and effective, safe, and sustained use of medicines are a feature of the journal, which has also been accepted for indexing on PubMed Central. The manuscript management system is completely online and includes a very quick and fair peer-review system, which is all easy to use. Visit http://www.dovepress.com/testimonials.php to read real quotes from published authors.

Submit your manuscript here: http://www.dovepress.com/drug-design-development-and-therapy-journal 